\title{
Native Lexical Innovation in Penang Hokkien: Thinking beyond Rojak
}

\author{
Catherine Churchman
}

A few years ago, in a box of yellowed papers at the back of a cluttered antique shop in Chulia Street in George Town, I came upon a small green volume entitled "Chinese New Terms and Expressions" that had been published in Shanghai in 1913. The author, Evan Morgan, had spent several years collecting and noting down recently coined Chinese words he came across in newspapers, magazines, and books, and his work was a testimony to the rapid changes that had occurred in the Chinese written and spoken language over the previous decades, as China transformed itself from empire to nation-state and words for new technology and new ideas had entered the language. Having spent the previous few weeks wandering around George Town collecting vocabulary for a dictionary of the Hokkien language as spoken in Penang, ${ }^{2}$ as I leafed through this volume it occurred to me that although many of the new Chinese terms it recorded were shared with other varieties of Hokkien - such as those spoken in Amoy and Taiwan - a fair number of these had not gained currency in the Hokkien of Penang. As Amoy and Taiwanese varieties have tended to follow the lead of Japanese and Mandarin in the creation of their modern vocabularies, Penang Hokkien vocabulary has, to some extent, modernized along a different trajectory. This is due in part to Penang Hokkien speakers' longstanding acceptance of loanwords from Malay and English - hence the common metaphor rojak 'spicy fruit-and-vegetable salad' - and their free use of these in place of native Hokkien vocabulary, but another significant contributing

1 All Hokkien words are transcribed according to the POJ or Church Romanization system with significant modifications for Penang pronunciation.

2 Although it is not used in either China or Taiwan, I employ "Hokkien" in its Southeast Asian sense as a catch-all for the spoken idioms of the Zhangzhou-Quanzhou districts of southern Fujian. The terms “Southern Min” or “Minnan” 閩南 as used in China can have a wider meaning encompassing related languages that not only includes the Zhangzhou-Quanzhou group of languages, but also Teochew and Hainanese (Zhou 2010: 1). 
factor to the divergence is Penangites' creative compounding of pre-existing Hokkien vocabulary in ways unknown to speakers of other varieties. The following describes both the historical context of this divergence in vocabulary, and examples of Penang Hokkien speakers' neologisms arranged according to some general categories.

Despite the name, "Penang Hokkien" as employed in this chapter refers not only to varieties of Hokkien spoken within the state of Penang, but also to closely related varieties spoken by the majority of Malaysian ethnic Chinese in the cities and towns along the west coast of the Malay Peninsula, from the north of Kuala Kangsar to the Thai border. Because of its geographical spread, Penang Hokkien is also sometimes known as Northern Malaysian Hokkien. This serves to distinguish it from the "Southern Malaysian Hokkien" spoken in the southern half of the Malay Peninsula and in Singapore, which is phonologically and grammatically different from the Northern variety.

Yet other more distantly-related varieties can be found further afield, in Northern Borneo (Sarawak), Northern Sumatra (Medan) and Southern Thailand (Phuket), and a related variety was also once spoken in the Chinatown of Rangoon. However, within Malaysia, Penang remains the most important centre for this language and was historically the centre from which it spread to other areas along the coast. Penang Hokkien has been the lingua franca of ethnic Chinese in northern Malaysia for over a century, but at present appears to be undergoing replacement by Mandarin as a result of longstanding education policies and changes in the home linguistic environment (Sim 2012; Ooi \& Tan 2017).

Penang Hokkien is based on the Haicheng 海澄 dialect of the Zhang-Quan 漳泉 subgroup of Southern Min languages, reflecting the speech of the homeland of the majority of the earliest Hokkien settler families prior to the middle of the nineteenth century (Jones 2009). However, intense contact with other languages, principally Malay, English, Cantonese, and Teochew, has significantly altered the vocabulary, tonal system, and syntactic structure of the base dialect to a greater of lesser degree that varies in accordance with a speaker's social network, age, and family and educational backgrounds (see Lim \& Teoh 2007; Lim 2010; Chuang et al. 2013; Soon 2014; Ye 2014; Churchman 2017; Hing 2017). The divergent development of all of these linguistic features in Penang Hokkien frequently impedes mutual intelligibility with Taiwanese and mainland Chinese varieties.

As the most immediately obvious difference between Penang Hokkien and other varieties, it is lexical borrowings from Malay that attracts the most scholarly and popular attention. Social media discourse around the language often revolves around such words, the perennial favourites being lui 鐳 for 'money' 
and sah-bûn 雪文 for 'soap' and their supposed derivations. ${ }^{3}$ However, lexical borrowing is only one of the factors behind the distinctive character of Penang Hokkien vocabulary, as a substantial amount of vocabulary difference between Penang and other varieties originates in different usages of native Hokkien vocabulary. One category of divergent usages is the retention in Penang of a number of words that have fallen out of use in other varieties. Two common examples are chit-chîi 一誰 for 'who' - used in the Hokkien translation of the Old Testament completed in 1884 - and thi $i^{n}-s \hat{\imath}$ 天時 for 'weather', both current in Penang but already obsolete in Taiwan and Amoy usage (the latter is known in Singapore). A further factor, much understudied and the subject of this chapter, ${ }^{4}$ is the rich vocabulary of neologisms that speakers of Penang Hokkien have derived through compounding and semantic extension of the elements shared with other varieties of Hokkien. These words, although derived from native Hokkien elements, are mostly unknown in the Hokkien-speaking world beyond Malaysia and Singapore and are generally not understood by Taiwanese or Amoy speakers of Hokkien.

Such neologisms can be categorized into two broad categories. The first includes words for things that speakers encountered in the multicultural, tropical environment of the Straits Settlements that were rarely encountered by or unknown to speakers of Hokkien in nineteenth-century Fujian, including types of clothing, building styles, foods, fruits, religious practices, customs, and colonial political or administrative institutions. The second category consists of words for the new technology and ideas that appeared in industrialized societies of the twentieth century. These were commonly encountered in all parts of the Hokkien-speaking world, but were invented or came into existence at a time in which the Penang Hokkien speech community was relatively isolated from other Hokkien speech communities. Over the last ten years I have been collecting these distinctive terms from conversations on the street, internet forums, the weekly Penang Hokkien Podcast, and a collection of published dictionaries and manuals of the language (Tan 2001; 2008; 2010; Kwok 2005; Lee Eng Kew 2007; de Gijzel 2013; Tan: 2016). I am also extremely grateful for the help of Sim Lee, Ooi Kee How, Simon Chee Hooi Lim, Khoo Salma, Tina Teoh and Alan Ong for making me aware of many of these special terms.

3 The former comes from Dutch duit via Malay and the latter either from Arabic or Portuguese sabun. These and subsequent Malay etymologies are from Jones (2007).

$4 \mathrm{Wu}(2014)$ appears to be the only pre-existing academic study of such words in Penang. Gao (2000) has made a list of unique native terms in the closely-related dialect of Medan and Zhou and Zhou (2000: 89-9o) provide a short list of neologisms in Singapore Hokkien. 
The last two decades of the nineteenth century and the first decade of the twentieth were an important time for the development of Modern Standard Chinese vocabulary. As Chinese began to take an interest in the technology, culture, and governmental systems of Western countries, hundreds of new words were created and imported into written Chinese, and from there made their way into the spoken vernacular languages of those literate in Chinese (including Vietnamese and Korean). Beginning in the 1840s, Chinese intellectuals created new Chinese compound words they came across in Western books, and after the 186os principally on the models provided by Japanese kanji compounds coined by Japanese writers, as Meiji Period Japan (1868-1912) quickly became a model for China of a successfully modernized, strong Asian nation (see Masini 1993). New terms in Chinese included words such as minzhu 'democracy' (appearing first in Chinese in 1864), zongjiao 'religion' (189o), kexue 'science' (1896), and dianbao (186os) 'telegraphy', based on Japanese min-

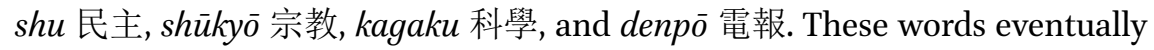
found their way into the spoken Chinese vernacular languages, and formed an important part of the vocabulary of the National Language (Guoyu 國語) based on the Peking dialect, promoted from the 1920s onward. Many words invented or borrowed into written Chinese over this period found their way into spoken Hokkien through the media and the education system. In the preface to his 1923 supplement to Carstairs Douglas' Hokkien dictionary of 1873, Thomas Barclay describes the changes in Hokkien vocabulary of the preceding halfcentury as follows:

Western civilization, to an increasing extent, has been welcomed, and new ideas in every department of thought and action have filled the minds of the people. These new ideas have demanded for their expression new terms, the addition of which has much enriched and extended the language.

BARCLAY 1923: i

Barclay's supplement added 271 pages of entries to Douglas' original 617 pages, an increase somewhere between a third to a half of new vocabulary. Hokkien speakers on Taiwan during the Japanese colonial period (1895-1945) were exposed directly to newly coined Japanese vocabulary through the Japanese education system, and borrowed words like iá-kiû 野球 'baseball', kháu-chō 
口座 'bank account', and $p \bar{e}^{n}-\bar{l}^{n}$ 病院 'hospital' - that were modelled directly on Japanese yakyū, kōza, and byōin - entered the Taiwanese Hokkien vernacular but were not adopted in written Chinese. After 1945, the exclusion of languages other than Mandarin from the education system in Taiwan intensified the influence of Mandarin on Taiwanese Hokkien, with the result that many vernacular Taiwanese expressions were replaced by their Mandarin equivalents pronounced according to Hokkien, such as the replacement of the native Taiwanese chò-sit-lâng 做穡儂 'farmer' with the Mandarinized term lông-bîn 農民 (Cheng 1987). Similar changes occurred in the Hokkien spoken in China. $\mathrm{Li}$ and $\mathrm{Xu}(2007)$ analyse changes in Amoy dialect vocabulary over a century as illustrated through Amoy dialect textbooks, noting not only changes in material and social culture as reasons for vocabulary change, but also the strong influence of Mandarin vocabulary, especially from the mid-twentieth century onwards.

During this period of rapid change in the vocabulary of Chinese languages, three factors combined to encourage Penang Hokkien to develop divergently from other varieties. The first and most basic factor was the disconnect between spoken Hokkien and forms of written Chinese, exacerbated in Penang by the heavy admixture of Malay, English, and other languages. The second was historically low levels of literacy amongst the Penang Hokkien speech community in written Chinese or proficiency in Mandarin, the two media through which neologisms entered other varieties of Hokkien. The third factor was the almost complete lack of exposure to other varieties of Hokkien and the relegation of Penang Hokkien to the home, the family, and everyday societal interactions. Until the late 1980s, little was published in Hokkien worldwide aside from a few textbooks and missionary texts, let alone in Penang Hokkien, nor was there much in the way of news media throughout most of the twentieth century to carry new vocabulary current in Chinese or Taiwanese Hokkien to the ears of Penang Hokkien speakers. These three factors are explained in more detail below.

Until relatively recent attempts at standardization by the ROC Ministry of Education, spoken varieties of Hokkien have historically maintained only a loose relationship with the Chinese written character. In pre-twentieth century texts, character usage was largely unsystematized (see Klöter 2005: 41-87 for details) and the Literary Chinese used in the education system and as the official written language of the Roc until 1919 presented extra problems for Hokkien speakers on account of its pronunciation being significantly different from what they used in their everyday vernacular. Writing about Chinese 
education in Malacca in 1839, Newbold quotes a report on a Chinese native school in Malacca describing the difficulties faced by those learning to read and write through Hokkien as follows:

In schools among the Fokien people, the practice of committing much to memory is not attended with so much benefit as might be expected, from the circumstance of their colloquial dialect being entirely different from that in which they read and learn; insomuch, that though persons may be well acquainted with the colloquial dialect, yet the dialect in which they read is so different, that much may be committed to memory without being understood. This forms a great barrier to improvement in Fokien schools, as the scholars have two dialects to acquire before they can understand or make themselves intelligible to others. The same is the case in Canton schools.

NEWBOLD 1839, vol. 1: 177

The "two dialects" in this case most likely refers to the difference between Literary Chinese and the colloquial vernacular. Both vernacular Cantonese and Hokkien differ greatly in grammar and vocabulary from Literary Chinese. However, for Cantonese speakers the reading pronunciation of texts and the pronunciation of the related morphemes in the spoken vernacular is largely identical, and it is only the word choice and grammatical idiom that distinguishes it from the literary style (see also Ding, this volume). For a Cantonese speaker, 'meat', 'person', and 'water' are pronounced yuk 肉, yan 人, and sui 水, no matter whether they are spoken or read off the page of a Chinese book. In contrast, a Hokkien speaker will use bah, lâng, and chúi when speaking, but when reading out from a page of Literary Chinese, read the Chinese characters out as jiók, jîn, and súi. It has been estimated that $33 \%$ of commonly used characters for written Taiwanese (that is, the written representation of the spoken vernacular) have a double reading, or more accurately, one character stands for what would be two separate morphemes in a phonetic script (Xu 200o: 62). This added an extra layer of complexity to an already complicated and ineffective language learning process. The result was that the literacy rate in Fujian was especially low. Edwin Joshua Dukes, a missionary who lived in southern Fujian in the 188os describes it the lowest in the country:

In the northerly provinces, where the Mandarin language is read and spoken, the proportion of readers is higher than in the south, where the dialects and languages are so numerous, and the written language coincides so little with the market tongues. The most deplorably ignorant 
province is Fu-kien. Intelligent and judicious colporteurs in that province have assured the writer that only one or two percent can read with sufficient hope that if they received the scriptures their own eyes could convey the meaning to their eyes and hearts.

DUKES 1885: 166-67

Newbold noted that in Malacca, Chinese tended to intermarry with Malays, and that the Malay language became the home language and the one acquired by children "to whom the later acquirement of Chinese must become a matter of time and difficulty" (Newbold 1839, vol. 1: 172). Later he notes that although Chinese from China were generally literate, "of those born in Malacca ... probably not one in ten (though they have been at school several years) is able to understand books written in the plainest style" (ibid. 179-80).

Learning to read Chinese, already an onerous task for a Hokkien speaker, was further compounded in Penang by the fact that many Malay terms and a certain number of Malay syntactic features had entered the language, especially that of the Baba families (Lim \& Teoh 2007, Lim 2010). In the last decades of the nineteenth century and the first decades of the twentieth, many Straits-born Chinese in Penang spoke Malay as their mother tongue rather than Hokkien. In 1913, William Shellabear refers to Baba Malay (a creolized form of Malay with a Hokkien substrate; see Aye in this volume) as "the mother-tongue of the majority of the Chinese women and children in the Straits Settlements", and "the language of the homes of the Straits-born Chinese - the most highly educated and most influential section of the Chinese community in the British possessions" (Shellabear 1913: 52). Judging by the popularity of the Malay translations of "Batu Gantong" - the pen-name of Chan Kim Boon 曾錦文 (1851-1920) Chinese who could speak Hokkien were more comfortable reading and writing in Malay or English than any form of written Chinese, and wrote fan letters to him in both of these languages. One of them, named Lim Tiouw Chuan from Taiping, recommended his Sam Kok三國 as a work "that should be in every Chinese home" (Batu Gantong 1892, vol. 5: iii-iv). Unlike many of his readers, Chan himself was a proficient reader of Chinese who had spent some years in Fujian, and his works contained glossaries of difficult or obscure Hokkien vocabulary explained in English and vernacular Malay.

Further complexity was added as a wave of migration of Chinese from China (known as the Sinkhek 新客; lit. 'new guests'), beginning in the second half of the nineteenth century, brought Chinese speaking other languages such as Cantonese and Teochew who introduced many features of their own native tongues into the Penang Hokkien. Throughout this period, English was the language of colonial administration and higher education, which resulted in 
English vocabulary and syntactic features entering the language, particularly from the mid-twentieth century onwards (Churchman 2017). Amidst these diverse origins of the Penang Hokkien vernacular, even a Penang Hokkien speaker who was a proficient reader and writer of Classical Chinese or Mandarin would be at a loss how to turn their everyday Hokkien vernacular to a written form in Chinese characters. Consequently, until the rise of interest in vernacular Penang Hokkien beginning in the early 200os, written representations of the spoken vernacular were rare and limited to a few wordlists, mentions and descriptions. Two notable examples are Lo Man Yuk's Chinese Names of Streets in Penang that provides a snapshot of vernacular vocabulary at the turn of the twentieth century (Lo 190o), and the Hokkien-Malay glosses contained in the Baba Malay translations of Chinese classic novels by Batu Gantong over three decades of the 189 os to the 1910s. ${ }^{5}$ Both of these writers used romanized forms of Hokkien accompanied by what they considered to be the appropriate Chinese characters.

Hou Hongjian's 侯鴻鑒 A Record of Travel in the Nanyang, published in 1920, offers a snapshot of Chinese language education in the first two decades of the twentieth century. Hou recounted his discussions with the headmasters of Chinese schools in Penang in October 1919, in which he was informed that there were twenty Chinese primary schools in Penang, fifteen boys' schools and five girls' schools, but that only five of these had rolls of more than 100 pupils, the Chunghwa Confucian School 孔聖廟中華國民型中學 boasting the highest roll of over 400 pupils (Hou 1920, vol. 2: 30a). Hou noted that in the Chunghwa School taught the first two years in Hokkien before switching to the "National Language" (Mandarin) in the third and fourth years (ibid., vol. 2: 31b.). Founded by the local business magnate Cheong Fatt Tze 張怩士 in 1904, this school was the first to use Mandarin as the medium of education but was likely teaching literacy in Classical Chinese rather than Vernacular Chinese (白話 Baihua) - a written form based on northern Chinese - as the written standard.

The Republican government in China began to popularize Baihua as the standard written form of Chinese from the 1920s onwards, and this began to filter into the Chinese education system in Penang (also see Hoogervorst, this volume, on Indonesia). Although it is not clear when various Chinese-medium schools in Penang shifted to the new form, the Chinese newspaper Penang Sin Poe 檳城新報, published from 1895 to 1941, gradually switched from Classical Chinese to Mandarin over the period from 1928 to 1930. This at least indicates

5 Two of the most notable translations being his Sam Kok 三國 (Luo Guanzhong's 羅貫中 Romance of the Three Kingdoms published from 1892-96) and Kow Chey Thian 猴齊天 (Wu Cheng'en's 吳承恩 The Journey to the West published from 1911-13). 
that the new style of reading and writing had become widespread by this time among those literate in Chinese. Although the adoption of Baihua reduced the distance between written Chinese and all of the spoken Sinitic languages to some extent, the distance between the structure and vocabulary of written Mandarin and that of spoken Penang Hokkien would still have constituted a considerable hurdle to Hokkien speakers' ability to relate what they had learnt to write in Mandarin back to their everyday language.

The total Chinese population of Penang in the year following Hou's visit was 135,288 , and that of Hokkiens 64,085 . Although it is impossible to calculate the number of proficient Chinese readers and writers in Penang, Hou's estimation from 1919 indicates that at the most, around 2,ooo children were attending schools in which they could acquire any kind of Chinese literacy, and that this was a relatively new phenomenon. In Penang of the pre-War period, there were many people who had had no chance to attend schooling of any kind, and those who did often attended only for a few years or attended English-medium schools. In addition, Penang Hokkien speakers often had to use Malay or English for social interactions and for official purposes and in higher education. They read Malay and English newspapers and books.

Popular entertainment in other varieties of Hokkien could have acted as a conduit in introducing new words from these varieties to Penang speakers, but such entertainment was not widely available to them. Entertainment in Cantonese and Mandarin was easily available in Malaysia from the 1980 s onwards, but Penang Hokkien speakers had relatively little exposure to entertainment and news in any variety of Hokkien until as late as the mid-2ooos. Ten-minute nightly news broadcasts in Hokkien were and continue to be broadcast nationally, but these have always been made in the Amoy dialect that is far removed from what is spoken in Penang. This changed in 2007 with Taiwanese programming through satellite $\mathrm{TV}$, such as Hua Hee Dai 歡喜台 started in 2007, or through sites such as Youtube. ${ }^{6}$

Therefore, during the period in which the vocabulary of written Chinese and hence, other varieties of Hokkien - was in a state of flux, the disconnect between written Chinese and spoken Hokkien, the limited spread of education in written Chinese, and intense contact with English and Malay affecting mutual intelligibility with other varieties all combined to insulate the majority of Penang Hokkien speakers from the major developments in Hokkien vocabulary in other parts of the Hokkien-speaking world well into the twenty-first century. The result of these combined factors was that speakers of Penang

6 For more on the recent sociolinguistic situation of Chinese languages in Malaysia, see Sim (2012). 
Hokkien were insulated from the trend of adopting words into Hokkien via graphic loans from Mandarin and instead derived original neologisms from their own everyday spoken language through compounding and semantic extension of pre-existing words. The vocabulary of Penang Hokkien therefore developed along a different trajectory from other varieties.

\section{$3 \quad$ Vocabulary Innovation by Compounding}

As Penang Hokkien compounds are derived from putting together common pre-existing words, they are more transparent in meaning to speakers than those borrowed from written Chinese in other varieties of Hokkien. Often in Literary Chinese, a single syllable will represent an idea but is only used as a bound morpheme, and unless one is familiar with its meaning and how it is used in other words, its meaning will be opaque. For instance, some of the examples in Table 5.1 relating to uniforms use the common morpheme $s a^{n}$ 衫 'shirt' for clothing in preference to hók 服 used in other varieties. As hók 服 appears only in the colloquial Penang Hokkien word hók-sāi 服侍, meaning 'to serve' or 'to worship', and not in words related to clothing, it did not occur to Hokkien-speaking Penangites when they came to derive words for uniforms.

Where Mandarin (and consequently Amoy Hokkien and Taiwanese due to their exposure to Mandarin) use two or three-character compounds to create concrete nouns, Penang Hokkien, lacking some of the syllabic morphemes transmitted through written Chinese, often prefers multisyllabic transparent compounds in which the sense of the word is immediately deducible from its constituent parts. Some terms are derived with the nominalizing particle $\hat{e}$ 个 and are either short noun phrases containing subordinate clauses or possessive noun phrases (see Table 5.1). When referring to occupations, Penang Hokkien can derive a noun phrase from a verb object phrase with the addition of $-\hat{e}$ "one who ...." However, these are often avoided in preference to short sentences expressing the same concept, for example "I am a civil servant" would be expressed as Wá chò chèng-hú-kang 我做政府工, literally meaning 'I do government work'.

A number of very basic words are expressed differently in Penang Hokkien from other varieties of Hokkien. These single Penang words often cover a broader range of meanings than those in other varieties, which distinguish them with distinct terms. When these words are used as components in compound words, the meanings are often unclear to speakers of other varieties (Table 5.2). 
TABLE 5.1 Transparent multisyllabic compounds

\begin{tabular}{|c|c|c|c|c|}
\hline $\begin{array}{l}\text { English } \\
\text { meaning }\end{array}$ & Penang & $\begin{array}{l}\text { Translation of } \\
\text { Penang expression }\end{array}$ & $\begin{array}{l}\text { Amoy/ } \\
\text { Taiwan }^{a}\end{array}$ & Mandarin \\
\hline $\begin{array}{l}\text { army } \\
\text { uniform }\end{array}$ & $\begin{array}{l}\text { peng-- } \hat{e}-s a^{n} \\
\text { 兵个衫 }\end{array}$ & $\begin{array}{l}\text { 'the clothes } \\
\text { of soldiers' }\end{array}$ & kun-hók 軍服 & junfu 軍服 \\
\hline $\begin{array}{l}\text { chopstick } \\
\text { holder }\end{array}$ & $\begin{array}{l}h \bar{e} \cdot-t \bar{u}--\hat{e} \\
\left(m i h_{-}-k i a^{n}\right) \\
\text { 下箸个(物件) }\end{array}$ & $\begin{array}{l}\text { 'the thing to put } \\
\text { chopsticks in' }\end{array}$ & $t \bar{t}$-lāng 箸籠 & $\begin{array}{l}\text { kuaizitong } \\
\text { 筷子筒 }\end{array}$ \\
\hline $\begin{array}{l}\text { civil } \\
\text { servant }\end{array}$ & $\begin{array}{l}\text { chò chèng- } \\
\text { hú-kang--ê } \\
\text { 做政府工个 }\end{array}$ & $\begin{array}{l}\text { 'someone who } \\
\text { works for the } \\
\text { government' }\end{array}$ & $\begin{array}{l}\text { kong-bū-oân } \\
\text { 公務員 }\end{array}$ & $\begin{array}{l}\text { gongwuyuan } \\
\text { 公務員 }\end{array}$ \\
\hline dentist & $\begin{array}{l}\text { pó·-chhùi- } \\
\text { khí--ê } \\
\text { 補㖨齒个 }\end{array}$ & $\begin{array}{l}\text { 'someone who } \\
\text { does fillings' }\end{array}$ & gê-i 牙醫 & yayi 牙醫 \\
\hline $\begin{array}{l}\text { fire } \\
\text { extinguisher }\end{array}$ & $\begin{array}{l}\text { kiù-hóe--ê } \\
\text { míh-kiàn } \\
\text { 救火个物件 }\end{array}$ & $\begin{array}{l}\text { 'the thing that } \\
\text { rescues from fires' }\end{array}$ & $\begin{array}{l}\text { biát-hóe-khi } \\
\text { 滅火器 }\end{array}$ & $\begin{array}{l}\text { miehuoqi } \\
\text { 滅火器 }\end{array}$ \\
\hline $\begin{array}{l}\text { ritual } \\
\text { implements }\end{array}$ & $\begin{array}{l}\text { pài Hút--ê } \\
\text { míh-kiàn }^{n} \\
\text { 拜佛个物件 }\end{array}$ & $\begin{array}{l}\text { 'things for } \\
\text { worshipping } \\
\text { the Buddha' }\end{array}$ & hoat-khi 法器 & faqi 法器 \\
\hline $\begin{array}{l}\text { school } \\
\text { uniform }\end{array}$ & $\begin{array}{l}o ́ h-t \hat{n g}-(\hat{e})-s a^{n} \\
\text { 學堂衫 }\end{array}$ & $\begin{array}{l}\text { 'the clothes for } \\
\text { school' }\end{array}$ & hāu-hók 校服 & $x i a o f u$ 校服 \\
\hline veterinarian & $\begin{array}{l}\text { khîm-siù--ê } \\
\text { ló-kun 离獸个 } \\
\text { 老君b }\end{array}$ & $\begin{array}{l}\text { 'doctor for } \\
\text { animals' }\end{array}$ & $s i \bar{u}-i$ 獸醫 & shouyi 獸醫 \\
\hline
\end{tabular}

a The examples for Amoy and Taiwan in this table and those following have been crosschecked through the Maryknoll English-Taiwanese Dictionary (Maryknoll 2013), the Minnan fangyan dacidian (Zhou 2006), and the Minnanhua Zhangqiang cidian (Chen 2006).

b Khim-siù 离獸 for 'animal' is obsolete in most other varieties or restricted to the meaning 'birds and beasts', having been replaced by the Japanese coinage tōng-bút 動物. Ló-kun 老君, the default term for 'doctor', is in fact the Malay loan dukun. This old term for a medicine man or medicine woman is disguised with the Chinese characters for 'elderly lord', the name of a Taoist deity. 
TABLE 5.2 Differences in base morphemes

\begin{tabular}{|c|c|c|c|}
\hline English & $\begin{array}{l}\text { Penang } \\
\text { Hokkien }\end{array}$ & Taiwan/Amoy & $\begin{array}{l}\text { Meaning of Penang } \\
\text { term in other varieties }\end{array}$ \\
\hline certificate & $j \bar{l}$ 字 & $\begin{array}{l}\text { chèng-bêng-su 證明書, } \\
j i \text { 字, ji-bú 字母 }\end{array}$ & $\begin{array}{l}\text { Chinese character, } \\
\text { written word }\end{array}$ \\
\hline $\begin{array}{l}\text { deity, idol, } \\
\text { divine }\end{array}$ & $\begin{array}{l}\text { ang-kong } \\
\text { 廷公 }\end{array}$ & $\begin{array}{l}\text { sin 神, sin-bêng 神明, } \\
\text { sin-siōng 神像 }\end{array}$ & idol, doll \\
\hline $\begin{array}{l}\text { film, movie, } \\
\text { TV programme }\end{array}$ & hi 戲a & $\begin{array}{l}\text { tiān-ián }{ }^{n} \text { 電影, } \\
\text { chiat-bók 節目 }\end{array}$ & a play \\
\hline food, cuisine & chiáh 食 & $\begin{array}{l}\text { chhài 菜, liāu-lí 料理, } \\
\text { chhan 餐 }\end{array}$ & to eat, consume \\
\hline $\begin{array}{l}\text { temple, building } \\
\text { for religious } \\
\text { worship, } \\
\text { monastery }\end{array}$ & $a m$ 庵 & $\begin{array}{l}b i \bar{o} \text { 廟, } s \bar{\imath} \text { 寺, } \mathbf{b} \\
a m \text { 庵 }\end{array}$ & $\begin{array}{l}\text { Buddhist monastery, } \\
\text { nunnery }\end{array}$ \\
\hline tree, plant & châng 欉 & $\begin{array}{l}\text { chhiū-á 樹仔, chhiū- } \\
\text { châng 樹欉, sit-bút 植物 }\end{array}$ & $\begin{array}{l}\text { measure word for } \\
\text { plants }\end{array}$ \\
\hline
\end{tabular}

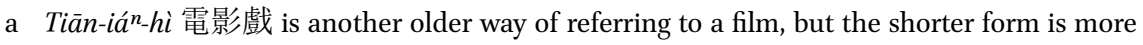
common.

b Both of these terms are included in the names of temples in Penang, for example Kék-Lók-Sī 極樂寺, the famous Buddhist temple in Air Itam, and Chôa-Biō 蛇廟, the Snake Temple at Bayan Lepas. The word $b i \bar{o}$ 廟 on its own is not unknown, however a Penang Hokkien speaker would tend to describe these collectively as am 庵.

The element am 庵 has the extended meaning of any large building used for religious worship, with the exception of Christian churches. Its derived compounds include Hoan-á-am 番仔庵 'a Mosque' (lit. Malay-am) - also hôe-kàu-tn̂g 回教堂 or hôe-kàu-biō 回教廟 - Siām-Hút-am 暹佛庵 'Siam Buddha-temple' for a Thai wat, ${ }^{7}$ Bâng-gà-líam 芒加里庵8 (lit. 'Bengali temple') for a Sikh temple, and Kè-lêng-á-am 吉寧仔庵 for a Hindu temple.

The word ang-kong 廷公 referred to a doll or idol, or the statue or sculpture of a deity, and these are the principal meanings it retains in other varieties of Hokkien. However, in Penang and northern Malaysia, although the original

7 Even though Thailand has not used the name "Siam" for almost seventy years, it still leads a vigorous existence in Penang as the default term, where other varieties of Hokkien have adopted Thài 泰.

8 Bâng-gà-lí 芒加里 derives erroneously from Bengali. 
meaning is still retained in some expressions, ${ }^{9}$ it has come to refer to the deities themselves, rather than their representations in stone and clay. Without further qualification, the word mainly refers to deities worshipped by the Chinese, but with the addition of the ethnic prefix Kè-lêng-á 吉寧仔, it may also refer to Hindu deities. The gods of monotheistic religions are seldom referred to in this fashion, presumably because they seldom are represented with statues. Sikhism is exceptional, and Sikhs are said to worship Bâng-gà-lí ang-kong 芒加里㝼公 'Bengali gods'. Larger Taoist temples are named angkong-am 廷公庵:10 these are administered by groups known as ang-kong-hōe 廷公會 'god clubs'. Small temples or residential houses that double up as places of worship are known as ang-kong-keng 㝼公間. The birthdays of Chinese deities according to the Lunar calendar are known as ang-kong-se. ${ }^{n}$ 爬公生 'god's birthday' and special sacrifices are made to them on such days. Talismans or good luck charms thought to be blessed by a god are known as ang-kong-hû 廷公符 'divine talismans' or sometimes just as hû. Lucky numbers received in a dream or received from a shaman are known as ang-kong-ji 㝼公字 divine characters' and used for gambling and fortune-telling purposes.

In other varieties of Hokkien, châng 樘 is a measure word or numerical coefficient for trees and plants. In other varieties, it is termed chhiū 樹 or chhiū-bók 樹木. The Penang usage for 'tree' probably derives from an older word chhiūchâng 樹欉, meaning a bush or shrub, which Penangites still sometimes use as the word for tree. In compounding, Penang Hokkien takes the final syllable of this words and uses it as a general term for all types of bushes, shrubs, plants and trees, whatever their size. Thus, a coconut palm is a iâ-châng 椰欉, bamboo is tek-châng 竹欉, a banana tree is a keng-chio-châng 弓蕉欉, a rambutan tree is âng-mô-tan-châng 紅毛丹欉, a coffee plant is a ko-pi-châng 㗝呸欉, and a rubber plant is chhiü-leng-châng 樹㑷欉.

$H i$ 戲 originally referred to traditional theatre performances and the stage on which these are performed, and in other varieties it still retains this meaning. In Penang, however, this is the ordinary word for a film or TV programme. For the traditional type of outdoor theatre performances, the Malay loan wayang is also used. Therefore, $k h o a^{n}$-hi 看戲 refers to watching a movie or TV programme, rather an attending a theatre performance as it would in other varieties. An Âng-mô.-hi 紅毛戲 'red-hair film' is a Hollywood movie or a

In Penang, this meaning is retained with the diminutive suffix $a$ 仔 and can be found in compound terms such as ang-kong-á 廷公仔 'a doll, a figurine, or a picture of a character or a face’ and ang-kong-á-pia ${ }^{n}$ 尤公仔餅 'small cakes shaped like an animal or with a picture of an animal on them made and eaten during the Mid-Autumn festival', also known as mascot mooncakes.

A less commonly used alternative is ang-kong-biō 㝼公廟. 
movie from a Western country, whereas a kúi-hi 鬼戲 'ghost film' is a horror film. To make or film a movie is to hip-hi 翟戲 'to take a film', modelled on hip siàu-éng 翕相影 'to take a photo', and to download one from the internet a more recent term, indicating that Penang Hokkien is still capable of this type of invention - is to lóh-hi 落戲 'to make a film come down'. Hì-tâi $i$ 戲臺 generally refers to a cinema in Penang, whereas in other varieties it usually means a theatre or stage.

In addition to its original meaning of 'a letter, word, or written character', $j \bar{l}$ 字 has the additional meaning of 'a certificate or official document' that is absent from modern Taiwanese or Amoy usage. Thus, a birth certificate is a chhut-se. ${ }^{n-j i}$ 出生字, ${ }^{11}$ a death certificate is sí-lâng-jī 死儂字 'dead person certificate', and a koa-sa-ji 啩吵字 is a will or document of power of attorney, the first part of which is borrowed from Malay kuasa 'power'.

Chiáh 食, aside from the meaning 'to eat' known in other varieties of Hokkien, has an additional function in Penang as a noun indicating different types of ethnic cuisine or dishes, and replaces a number of terms in other varieties of Hokkien. Âng-mô-chiáh 紅毛食 is a general term for Western food, Hoan-á-chiáh 番仔食 refers to Malay food (nasi Melayu), Chinese food is Tn̂g-lâng-chiáh 唐儂食, and Siām-chiáh 暹食 refers to Thai food. This way of distinguishing Chinese, Western, Malay, and Indian food is just one example of a very large class of compounds in Penang Hokkien associated with the four main ethnic groups that the speakers of the language distinguished in their daily life, as will be discussed in the next section.

"Ethnic" Compounding Prefixes Âng-mô., Tĥg-lâng, Hoan-ná, and Kè-lêng-á

Prior to the nineteenth century, things the Chinese saw or knew to be foreign imports were prefixed variously with 胡 ( $\mathrm{hu}$ ), 洋 (yang), 番 (fan) and so on, to indicate their foreignness. Once used in this manner, they no longer counted as adjectives, but were fixed as part of the word (Masini 1993: 124-25). As a result of being spoken in a multicultural society, Penang Hokkien has created many different words for the social and material cultures they encountered through prefixing them in different ways, depending on which groups they perceived them to be associated with. Marked categories of the "foreign" are subdivided into Âng-mô. 紅毛 'Western', Hoan-á 番仔 'Malay', and Kè-lêng-á 吉寧仔 'Indian', with an additional prefix Tn̂g-lâng 唐儂 for Chinese things that

11 An alternative form is chhut-se.n-chóa 出生紙 'birth paper'. 
were the once the norm, but in a multicultural context require a prefix to mark them out as specifically Chinese. ${ }^{12}$ The preceding four terms are known in the geographically close varieties spoken in Singapore and Medan, but Penang Hokkien has been especially creative in using them for derived compounds.

The term Âng-mô. 紅毛 'red-hair' is both the general term for Westerners or Europeans, but also has a narrower meaning that refers specifically to English-speaking peoples. The word was once in widespread usage throughout East and Southeast Asia, where it generally meant either Dutch or English people depending on the colonial context (see Ding, this volume). The term is still well-known in Singapore, even in the local variety of English, and is also used in Thai and Cambodian Teochew, and its cognates are used in Borneo Hakka. Âng-mô. has a wide range of uses in Penang for compounding unparalleled in other varieties. ${ }^{13}$ Ang-mô. was already very widely used for compounding by 1900. Lo Man Yuk records seven names that use it, including Âng-mô--kong-koan 紅毛公館 'town hall', the Âng-mô--tōa-lé-pài-tng 紅毛大禮 拜堂 'St. George's church', and Âng-mô-ón 紅毛學 'Penang Free School'.

Compounds relating to people of English or Western ethnic background include Âng-môo-kián ${ }^{n}$ 紅毛团 'red-hair children' for Western children, Âng-mô.-cha-bó. 紅毛查某 'a Western woman', Âng-mồ-pô 紅毛婆 'red-hair wife' as a slightly derogatory term for a Western woman, and Âng-mô--kâu 紅毛猴 'red-haired monkey' as a not particularly polite way of referring to a Western man. To be or do something âng-mô.-khóan 紅毛款 'red-hair-style' is a Western way or style of doing something. As the language typically spoken by the type of Westerners with whom the Penang Chinese had the most frequent intercourse, Âng-mô. has the extended meaning of the English language as spoken or written (in Medan Hokkien it often referred to Dutch).Âng-mô.-sái 紅毛屎 'red-hair shit' derives from the longer expression chiáh-âng-mồ-sái 食紅毛屎 'to eat the red-hair shit', the literal meaning of which is to receive an English education. The short form is used as a noun to refer to someone educated in an English-medium school who knows no written Chinese, and is frequently employed jocularly or in a self-deprecatory manner.

12 For example $s a^{n}$ 衫 is the general term for clothing, and Thy-lâng-san 唐儂衫 now refers to traditional Chinese clothing such as cheongsams. At some point in the past, when Chinese styles of dress were the norm, Western clothing would presumably have been $\hat{A} n g-m \hat{o}-s a^{n}$ 紅毛衫.

13 A significant number of these terms existed in mid-century Malayan Cantonese as well (see Bruce 1954: 122), but these are seldom used nowadays. A few of these words still exist other varieties of Hokkien: âng-mô--thó - 紅毛土 (Taiwan) or âng-mồ-thó. 紅毛灰 (China) for 'cement' and âng-mô--tan 紅毛丹 for 'rambutan' (see also Ding, this volume). 
Another use of $\hat{a} n g-m \hat{o}$. 紅毛 is as a prefix is used to mark things or concepts associated with Western or colonial culture, often in contrast to their perceived equivalents in Chinese culture (Table 5.3). Sometimes these are used only when a distinction needs to be made, for example âng-mô--chhit-goéh 紅 毛七月 'red-hair seventh month' is July only when it needs to be disambiguated from the seventh month of the Chinese lunar calendar. Ang-mô--tang-cheh 紅 毛冬節 'red-hair's Winter Solstice', a common word for Christmas, is formed on analogy with the Chinese festival of Tang-cheh 冬節 'Winter Solstice', because the two festivals are only four days apart. ${ }^{14}$ However, the term for All Souls' Day, âng-mô-chheng-bêng 紅毛清明, is named after the tomb Sweeping Day or the Chheng-bêng 清明 festival, not because of the similar date, but because both are festivals at which the dead are remembered.

TABLE 5.3 Compounds with Âng-mô. 'Westerner'

\begin{tabular}{|c|c|c|c|}
\hline English & $\begin{array}{l}\text { Penang } \\
\text { Hokkien }\end{array}$ & $\begin{array}{l}\text { Meaning of } \\
\text { Penang term in } \\
\text { other varieties }\end{array}$ & $\begin{array}{l}\text { Amoy/Taiwan } \\
\text { equivalent }\end{array}$ \\
\hline All Souls' Day & $\begin{array}{l}\text { âng-mô-chheng- } \\
\text { bêng 紅毛清明 }\end{array}$ & $\begin{array}{l}\text { red-hair tomb- } \\
\text { sweeping day }\end{array}$ & $\begin{array}{l}\text { tui-su i-bông-jít } \\
\text { 追思已亡日 }\end{array}$ \\
\hline $\begin{array}{l}\text { Arabic numerals (as } \\
\text { opposed to those in } \\
\text { Chinese characters) }\end{array}$ & $\begin{array}{l}\hat{a n g}-m \hat{o} \cdot-h \bar{o}-b e ́ \\
\text { 紅毛號碼 }\end{array}$ & $\begin{array}{l}\text { red-hair } \\
\text { numbers }\end{array}$ & $\begin{array}{l}\text { A-la-pek sò--jī } \\
\text { 阿拉伯數字 }\end{array}$ \\
\hline botanical gardens & $\begin{array}{l}\hat{a} n g-m \hat{o} \cdot-h o a-h u \hat{\imath}^{n} \\
\text { 紅毛花園 }\end{array}$ & $\begin{array}{l}\text { red-hair flower } \\
\text { garden }\end{array}$ & sitt-bút-hn̂ng 植物園 \\
\hline $\begin{array}{l}\text { British army; British } \\
\text { soldiers }\end{array}$ & $\begin{array}{l}\hat{a} n g-m \hat{o} \cdot-p e n g \\
\text { 紅毛兵 }\end{array}$ & $\begin{array}{l}\text { red-hair } \\
\text { soldiers }\end{array}$ & Eng-kun 英軍 \\
\hline $\begin{array}{l}\text { British colonial } \\
\text { period }\end{array}$ & $\begin{array}{l}\text { âng-mô·-chhiú } \\
\text { 紅毛手 }\end{array}$ & red-hair hand & $\begin{array}{l}\text { Eng-kok sit-bîn--ê sî-tài } \\
\text { 英國殖民个時代 }\end{array}$ \\
\hline bungalow & $\begin{array}{l}\hat{a n g}-m \hat{o} \cdot-l a \hat{u} \\
\text { 紅毛樓 }\end{array}$ & $\begin{array}{l}\text { red-hair } \\
\text { building }\end{array}$ & (no exact translation) \\
\hline Christmas & $\begin{array}{l}\text { ang-mô-tang-cheh } \\
\text { 紅毛冬節 }\end{array}$ & $\begin{array}{l}\text { red-hair winter } \\
\text { solstice }\end{array}$ & $\begin{array}{l}\text { Sèng-tàn 聖誕, Sèng- } \\
\text { tàn-chiat 聖誕節 }\end{array}$ \\
\hline
\end{tabular}

14 Alternatives are Ia-So-se.n 耶穌生 'Jesus' birthday' and Hōng-kàu-se.n 奉教生 'Catholicism birthday'. 
TABLE 5.3 Compounds with Âng-mô. 'Westerner' (cont.)

\begin{tabular}{|c|c|c|c|}
\hline English & $\begin{array}{l}\text { Penang } \\
\text { Hokkien }\end{array}$ & $\begin{array}{l}\text { Meaning of } \\
\text { Penang term in } \\
\text { other varieties }\end{array}$ & $\begin{array}{l}\text { Amoy/Taiwan } \\
\text { equivalent }\end{array}$ \\
\hline $\begin{array}{l}\text { English first name } \\
\text { (either official or } \\
\text { unofficial, used } \\
\text { in addition to or in } \\
\text { place of one's } \\
\text { Chinese name) }\end{array}$ & $\begin{array}{l}\hat{a n g}-m \hat{o} \cdot-m i \hat{a} \\
\text { 紅毛名 }\end{array}$ & red-hair name & $\begin{array}{l}\text { Eng-bûn-miâ } \\
\text { 英文名 }\end{array}$ \\
\hline English language & $\begin{array}{l}\hat{a} n g-m \hat{o} \cdot(-\bar{o} a) \\
\text { 紅毛(話) }\end{array}$ & $\begin{array}{l}\text { red-hair } \\
\text { language }\end{array}$ & Eng-gú Eng-gí 英語 \\
\hline $\begin{array}{l}\text { Roman alphabet, } \\
\text { Roman letters, } \\
\text { written English }\end{array}$ & âng-mố-ji 紅毛字 & $\begin{array}{l}\text { red-hair } \\
\text { characters }\end{array}$ & $\begin{array}{l}\text { Lô-má-ji 羅馬字, } \\
\text { Peng-im 拼音, } \\
\text { Eng-bûn 英文 }\end{array}$ \\
\hline $\begin{array}{l}\text { solar calendar } \\
\text { (New Year beginning } \\
\text { on } 1 \text { January) }\end{array}$ & 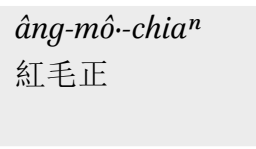 & $\begin{array}{l}\text { red-hair first } \\
\text { month }\end{array}$ & $\begin{array}{l}\text { goân-tàn 元旦 } \\
\text { (Amoy), sin-nî 新年 } \\
\text { (Taiwan) }\end{array}$ \\
\hline solar calendar year & $\begin{array}{l}\hat{a} n g-m \hat{o} \cdot-n \hat{\imath} \\
\text { 紅毛年 (also used } \\
\text { in Singapore) }\end{array}$ & red-hair year & iông-lék-nî 陽曆年 \\
\hline sweets & $\begin{array}{l}\hat{a n g} \text {-mồ-thn̂ng } \\
\text { 紅毛糖 }\end{array}$ & red-hair sugar & $\begin{array}{l}\text { thn̂n-á 糖仔, thn̂g-kó } \\
\text { 糖果 }\end{array}$ \\
\hline tomato & 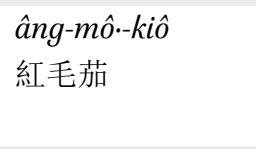 & red-hair brinjal & $\begin{array}{l}\text { tho-ma-toh (Taiwan), } \\
\text { chhàu-khi-á 臭柿仔 } \\
\text { (Amoy) }\end{array}$ \\
\hline $\begin{array}{l}\text { Western age (when } \\
\text { it needs to be } \\
\text { disambiguated for } \\
\text { official purposes } \\
\text { from the Chinese } \\
\text { age that adds an extra } \\
\text { year) }\end{array}$ & $\begin{array}{l}\text { ang-mô--hòe } \\
\text { 紅毛歲 }\end{array}$ & red-hair years & \\
\hline $\begin{array}{l}\text { Westerner, white } \\
\text { foreigner; the English } \\
\text { language, English as a } \\
\text { school subject }\end{array}$ & $\begin{array}{l}\text { âng-mô 紅毛 } \\
\text { (also used in } \\
\text { Singapore) }\end{array}$ & red hair & $\begin{array}{l}\text { gōa-kok-lâng 外國 } \\
\text { 人, a-tok-á 阿啄仔 } \\
\text { (Taiwan), hoan-á 番仔 } \\
\text { (Amoy), Eng-gú 英語, } \\
\text { Eng-bûn 英文 }\end{array}$ \\
\hline
\end{tabular}


The last four terms are connected specifically to things associated with the British colonial period and require some historical context. Âng-mồ-lâu 紅毛 樓 'red-hair building' refers to the kind of luxurious bungalow that Westerners owned and lived in in colonial times, and does not correspond neatly to any term in Taiwanese or Amoy Hokkien. The word is also used in a jocular sense as a term for a bump on the head received from a blow. Âng-mô--hoa-hui ${ }^{n}$ 紅毛花園 'the red-hairs' garden' originally referred specifically to the Botanical Gardens at Air Itam, but through association this term ended up being used by Penangites overseas to translate the English names for any botanical gardens. Âng-mô. remains a productive prefix in Penang Hokkien; a brand of craft beer recently released in Penang was humorously named "Ang Moh Leng Te" 紅毛冷茶 'the red-hairs' cold tea'.

Tĥg-lâng 唐儂 'Tang person' is the second most common of the ethnic prefixes, indicating Chinese ethnicity, and is generally used for those who do not hold Chinese nationality. The term predates modern Chinese concepts of nationalism, whilst still recognizing commonalities of culture and language with other Chinese groups such as Cantonese and Hakkas. ${ }^{15}$ The related terms T'āng-yān, Tong-nyin, and Tĥng-nâng exist in spoken Cantonese, Hakka, and Teochew respectively, but T'öng-yān is generally no longer used amongst younger Cantonese speakers in Malaysia, for whom Wā-yān, modelled on Mandarin Huaren 華人, is the preferred term. A feature of Penang-style Hokkien is the use of the disyllabic Tñg-lâng 唐儂 in the creation of new compound words, where earlier usage preferred the monosyllable Thi 唐. Barclay's Dictionary (1873) and Francken and de Grijs' Dictionary (1889) both list Tn̂g-lâng with the meaning 'a Chinese', but list only the compounds Tĥng-ōa 唐話 for the Chinese language and Thng-j $\iota$ 唐字 for Chinese characters, ${ }^{16}$ and Barclay's supplement of 1923 does not contain any new compounds with either Tĥng or Tĥng-lâng. In contrast, Penang Hokkien has many compounds prefixed with Thig-lâng to mark connection with Chinese material and social culture (Table 5.4). In this way, Penang Hokkien speakers differentiate them from the similar features in the foreign cultures to which Chinese in the Straits Settlements were exposed.

15 The name Tĥ-lâng first appears in a Southeast Asian context in Ma Huan's 馬歡 1433 description of Java his book The Overall Survey of the Ocean's Shores (瀛涯勝覽 Yingyai shenglan) as a collective term for people from Guangdong, Zhangzhou, Quanzhou, and other places who have come live in Java, some of whom had converted to Islam.

16 Medhurst (1832: 661) has both the literary (Tông-jîn) and colloquial (Tîng-lâng) reading. 
TABLE 5.4 Compounds with Tĥ̀-lâng 'Chinese'

\begin{tabular}{|c|c|c|c|}
\hline English & $\begin{array}{l}\text { Penang } \\
\text { Hokkien }\end{array}$ & $\begin{array}{l}\text { Meaning of } \\
\text { Penang term in } \\
\text { other varieties }\end{array}$ & Amoy/Taiwan equivalent \\
\hline $\begin{array}{l}\text { age according to } \\
\text { Chinese reckoning } \\
\text { (usually one's Western } \\
\text { age plus one) }\end{array}$ & $\begin{array}{l}\text { Tn̂g-lâng-hòe } \\
\text { 唐儂歲 }\end{array}$ & $\begin{array}{l}\text { Tang person } \\
\text { age }\end{array}$ & hòe歲 \\
\hline $\begin{array}{l}\text { birthday according to } \\
\text { the lunar calendar }\end{array}$ & $\begin{array}{l}\text { Tĥn-lâng- } \\
\text { se.n-jit } \\
\text { 唐儂生日 }\end{array}$ & $\begin{array}{l}\text { Tang person } \\
\text { birthday }\end{array}$ & long-lék se $e^{n_{-j} i t}$ 農曆生日 \\
\hline Chinese characters & $\begin{array}{l}\text { Tĥg-lâng-jī } \\
\text { 唐儂字 }\end{array}$ & $\begin{array}{l}\text { Tang person } \\
\text { characters }\end{array}$ & Hàn-jī 漢字 \\
\hline $\begin{array}{l}\text { Chinese doctor, } \\
\text { doctor of тсм }\end{array}$ & $\begin{array}{l}\text { Tĥg-lâng- } \\
\text { sin-se.n } \\
\text { 唐儂先生 }\end{array}$ & $\begin{array}{l}\text { Tang person } \\
\text { master }\end{array}$ & tiong-i 中醫 \\
\hline $\begin{array}{l}\text { Chinese language; } \\
\text { Mandarin }\end{array}$ & $\begin{array}{l}\text { Tĥg-lâng-ōa } \\
\text { 唐儂話 }\end{array}$ & $\begin{array}{l}\text { Tang person } \\
\text { speech }\end{array}$ & $\begin{array}{l}\text { Tiong-bûn 中文, Tiong- } \\
\text { kok-ōe 中國話, Hôa-gú } \\
\text { 華語, Kok-gí 國語, } \\
\text { Phó-thong-ōe 普通話 }\end{array}$ \\
\hline $\begin{array}{l}\text { Chinese lunar } \\
\text { calendar }\end{array}$ & $\begin{array}{l}\text { Tĥg-lâng- } \\
\text { láh-jitt-tô. } \\
\text { 唐儂曆日圖 }\end{array}$ & $\begin{array}{l}\text { Tang person } \\
\text { calendar }\end{array}$ & kū-lék 舊曆, lông-lék 農曆 \\
\hline $\begin{array}{l}\text { Chinese-medium } \\
\text { school }\end{array}$ & $\begin{array}{l}\text { Tĥng-lâng- } \\
\text { óh(-tĥg) } \\
\text { 唐儂學(堂) }\end{array}$ & $\begin{array}{l}\text { Tang person } \\
\text { school }\end{array}$ & $\begin{array}{l}\text { Tiong-bûn hák-hāu 中文 } \\
\text { 學校 }\end{array}$ \\
\hline Chinese name & $\begin{array}{l}\text { Tĥn-lâng- } \\
\text { miâ 唐儂名 }\end{array}$ & $\begin{array}{l}\text { Tang person } \\
\text { name }\end{array}$ & Tiong-bûn-miâ 中文名 \\
\hline Chinese New Year & $\begin{array}{l}\text { Tĥg-lâng- } \\
\text { chia }^{n} \text { 唐儂正 }\end{array}$ & $\begin{array}{l}\text { Tang person } \\
\text { first month }\end{array}$ & $\begin{array}{l}\text { sin-chia }{ }^{n} \text { 新正, kòe-nî過年, } \\
\text { chhun-chiat 春節 (Amoy) }\end{array}$ \\
\hline $\begin{array}{l}\text { Chinese person, } \\
\text { Overseas Chinese; } \\
\text { Chinese (language), } \\
\text { Chinese (school } \\
\text { subject) }\end{array}$ & $\begin{array}{l}\text { Tĥg-lâng } \\
\text { 唐儂 }\end{array}$ & Tang person & $\begin{array}{l}\text { Hàn-chók 漢族 (Amoy), } \\
\text { Hôa-jîn 華人, Tiong-bûn } \\
\text { 中文, Tiong-kok-ōe 中國 } \\
\text { 話, Hôa-gú 華語, Phó-- } \\
\text { thong-ōe 普通話 }\end{array}$ \\
\hline Chinese tea & $\begin{array}{l}\text { Tĥg-lâng-tê. } \\
\text { 唐儂茶 }\end{array}$ & Tang person tea & $t \hat{e}$ 茶 \\
\hline
\end{tabular}


TABLE 5.4 Compounds with Tĥng-lâng 'Chinese' (cont.)

\begin{tabular}{|c|c|c|c|}
\hline English & $\begin{array}{l}\text { Penang } \\
\text { Hokkien }\end{array}$ & $\begin{array}{l}\text { Meaning of } \\
\text { Penang term in } \\
\text { other varieties }\end{array}$ & Amoy/Taiwan equivalent \\
\hline $\begin{array}{l}\text { third month of the } \\
\text { lunar calendar }\end{array}$ & $\begin{array}{l}\text { Tĥg-lâng } \\
s a^{n} \text {-goéh } \\
\text { 唐儂三月 }\end{array}$ & $\begin{array}{l}\text { Tang person } \\
\text { March }\end{array}$ & long-lék sa-goéh 農曆三月 \\
\hline $\begin{array}{l}\text { to be conservative in } \\
\text { one's attitudes; to have } \\
\text { old-fashioned Chinese } \\
\text { ideas }\end{array}$ & $\begin{array}{l}\text { Thig-lâng-sim } \\
\text { 唐儂心 }\end{array}$ & $\begin{array}{l}\text { Tang person } \\
\text { heart }\end{array}$ & pó-siú 保守 \\
\hline $\begin{array}{l}\text { to study in a Chinese- } \\
\text { medium school }\end{array}$ & $\begin{array}{l}\text { thák Tĥ- } \\
\text { lâng-chhe·h } \\
\text { 讀唐儂冊 }\end{array}$ & $\begin{array}{l}\text { read Tang } \\
\text { person books }\end{array}$ & $\begin{array}{l}\text { thák tiong-bûn hák-hāu } \\
\text { 讀中文學校 (Taiwan), } \\
\text { thák tiong-bûn óh-tn̂g } \\
\text { 讀中文學堂 }\end{array}$ \\
\hline $\begin{array}{l}\text { Traditional Chinese } \\
\text { Medicine }\end{array}$ & $\begin{array}{l}\text { Tn̂g-lâng-ióh } \\
\text { 唐儂藥 }\end{array}$ & $\begin{array}{l}\text { Tang person } \\
\text { medicine }\end{array}$ & $\begin{array}{l}\text { tiong-ióh 中藥, Hàn-ióh } \\
\text { 漢藥 }\end{array}$ \\
\hline
\end{tabular}

In the past, Thy-Soa ${ }^{n}$ 唐山 (lit. 'Tang Mountain') was the common vernacular word for 'China' in almost all ethnic Chinese communities outside China, who had migrated from the southern coast of China. The term has the connotations of the "old country" and in Penang, those who had been born in China and spent a portion of their life there were known as Thy-Soan-lâng 唐山儂. An additional term, Tĥg-Soa ${ }^{n} a-p e \cdot h$ 唐山阿伯 (lit. 'Tang Mountain uncle') refers to the older generation of men who were born and grew up in China before

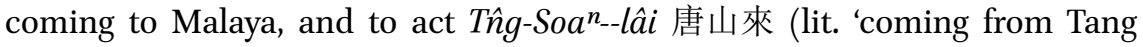
Mountain') is used for perceived unfavourable characteristics or conservative behaviour associated with these people. It is only recently that Tñg-Soan ${ }^{n}$ 唐山 for 'China' has become archaic and only older people use it, whereas people under the age of sixty would use Tiong-Kok 中國. ${ }^{17}$ Nevertheless, the distinction between a Tĥg-lâng and a Tiong-Kok-lâng 中國儂 is still maintained, in

17 This may be because of its associations with the expression túin ${ }^{n} \hat{n} g-S_{0} a^{n}$ 轉唐山 'to return to China' being used as a euphemism for death. 
the way that Huaren 華人 'an ethnic Chinese' and Zhongguoren 中國人 'a PRC national' are marked off in Malaysian Mandarin.

The term Hoan-á 番仔 is used in all varieties of Hokkien, but has differing meanings depending on where Hokkien is spoken. Its most basic meaning lies somewhere between 'savage' and 'foreigner', but in different varieties the meaning has narrowed and became attached to specific groups of people, usually the indigenous peoples in the lands to which Hokkiens have migrated. In Taiwanese it refers to Formosan aboriginals, ${ }^{18}$ in the Philippines generally to Tagalogs, in Thailand to native Thais in contrast to Thai Chinese, and in Amoy - where there are no indigenous people other than the locals - it refers to Westerners, substituting the last syllable of the older term for Westerners âng-mô--hoan 紅毛番 for the whole word, where other varieties have dropped it. Hoan-á was formerly used in both Amoy and Taiwan with a wider meaning, marking things that had come from overseas, such as hoan-á-hóe 番仔火 'matches'. In Penang, the word has narrowed its meaning and refers specifically to Malays. It is used in a similar way to the above two terms: to mark out things associated with Malay culture. The offensive "savage" connotation of the word has generally been lost. In contrast to Amoy Hokkien, where the word is falling out of use, Hoan-á, like Âng-mô., has taken on a life of its own. Thus a Hoan-á-kián 番仔囝 'Malay son' is a young Malay man, a Hoan-á-khu 番仔區 is an area where Malays form the majority of the population, and Hoan-á-chiáh 番仔食 refers to Malay cuisine (nasi Melayu). The word Hoan-á also refers to the Malay language as spoken or as a subject taught at school. To kóng Hoan-ná 講番仔 is to speak Malay, and Hoan-á-chhe.h 伊番仔冊 (lit. 'Malay books') refers to Malay-medium schooling. As the Roman (Rumi) script has long replaced Arabic-based Jawi as the most common mode of writing Malay, the term Hoan-á-ji 番仔字 (lit. 'Malay words') refers to written Malay in roman letters, whereas the older Arabic-based Jawi script - still a fairly common sight in Malaysia - is termed tāu-ghe-ji 豆芽字 'bean sprout letters' because of its resemblance to bean sprouts. The religion of the Malays, Islam, although generally termed Hôe-kàu 回教, is also referred to with Hoan-á in a few compounds (Table 5.5).

18 This usage is now considered offensive, and the neutral goân-chú-bîn 原住民 is now the preferred term. 
TABLE 5.5 Compounds with Hoan-á 'Malay'

\begin{tabular}{|c|c|c|c|}
\hline English & $\begin{array}{l}\text { Penang } \\
\text { Hokkien }\end{array}$ & $\begin{array}{l}\text { Meaning of Penang } \\
\text { term in other varieties }\end{array}$ & $\begin{array}{l}\text { Amoy/Taiwan } \\
\text { equivalents }\end{array}$ \\
\hline $\begin{array}{l}\text { Eid, } \\
\text { Hari Raya }\end{array}$ & $\begin{array}{l}\text { Hoan-á-chia }{ }^{n} \\
\text { 番仔正 }\end{array}$ & [not understood] & Khai-chai-cheh 開齋節 \\
\hline $\begin{array}{l}\text { Malay } \\
\text { person; } \\
\text { Malay } \\
\text { language }\end{array}$ & $\begin{array}{l}\text { Hoan-á } \\
\text { 番仔 }\end{array}$ & $\begin{array}{l}\text { Westerner (Amoy), } \\
\text { Indigenous Formosan } \\
\text { (Taiwan) }\end{array}$ & Má-lâi-lâng 馬來儂 \\
\hline Mosque & $\begin{array}{l}\text { Hoan-á-am } \\
\text { 番仔庵 }\end{array}$ & [not understood] & chheng-chin-sī 清真寺 \\
\hline $\begin{array}{l}\text { to convert } \\
\text { to Islam }\end{array}$ & $\begin{array}{l}\text { jíp-Hoan } \\
\text { 入番a }\end{array}$ & $\begin{array}{l}\text { [not used, could be } \\
\text { taken to mean to } \\
\text { marry into an } \\
\text { indigenous family } \\
\text { in Taiwan] }\end{array}$ & $\begin{array}{l}\text { kui-hiòng hôe-kàu } \\
\text { 歸向回教 (Taiwan) }\end{array}$ \\
\hline $\begin{array}{l}\text { to speak } \\
\text { Malay }\end{array}$ & $\begin{array}{l}\text { kóng hoan-ná } \\
\text { 講番仔 }\end{array}$ & $\begin{array}{l}\text { to speak English } \\
\text { (Amoy), b to speak an } \\
\text { indigenous Formosan } \\
\text { language (Taiwan) }\end{array}$ & kóng Má-lâi-ōe 講馬來話 \\
\hline
\end{tabular}

a A calque from Malay masuk Melayu in the same meaning.

b Taiwanese and Amoy would demand that the $\bar{o} e$ 話 'language' suffix is used. In Penang Hokkien, this is pronounced $\bar{o} a$ and is optional.

The last of the four most common ethnic prefixes is not a native Hokkien word, but is noted here as it functions in the same way as the above three. This is Kè-lêng-á 吉寧仔, usually translated carelessly into English as 'Indian', which refers specifically to Tamil-speaking Hindu Malaysians of Indian descent, and derives from the Malay Keling. This word ultimately derives from Sanskrit Kălinga, the name of an old kingdom on the Coromandel Coast mentioned in the second chapter of the Sejarah Melayu 'Malay Annals'. Sensitivities around its use - due to the erroneous belief that the term originates from the onomatopoeic "clink-clink" of either Indian foot-bangles or the chains of indentured labourers - have resulted in some speakers using İn-tō. 印度 to replace it in recent years. However, this word makes no distinction between Indian nationals and Malaysian Indians, and also fails to take into account the linguistic and cultural differences amongst different groups of Indians, 
as Kè-lêng-á in most contexts refers to Tamil speakers specifically. Therefore $K \grave{e}$-lêng-á-ōa 吉寧仔話 is the Tamil language, and it is written in Kè-lêng-á-ji 吉寧仔字 (lit. 'Kling characters'), the Tamil script. Some exceptions to this are the terms Kè-lêng-á-hi 吉寧仔戲, which refers to any Indian films, be they from Bollywood or Kollywood, Kè-lêng-á-hióh 吉寧仔箬 'Indian leaves' for curry leaves, and terms relating to the Hindu religion. Hindu gods and notable Hindu temples in Penang are known as Kè-lêng-á ang-kong 吉寧仔赶公, although Kè-lêng-á-am 吉寧仔庵 is also used in the latter meaning. To pray to these deities or pài Kè-lêng-á ang-kong 拜吉寧仔旭公 also has the extended meaning of being a Hindu. Kè-lêng-á-chia ${ }^{n}$ 吉寧仔正 'Indian New Year' is the festival of Deepavali, although - like Hoan-ná-chian (Hari Raya) - this festival is unconnected to the advent of a new year; chia ${ }^{n}$ 正 has undergone a shift in meaning to indicate the most important festival in the religious calendar rather than a

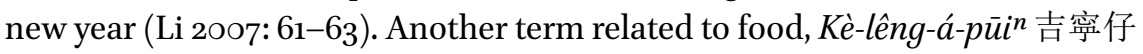
飯, refers to Indian-style curries served with steamed rice, but is also used in a similar way to English "porridge": as a metaphor for prison food. To say someone is chiáh-Kè-lêng-á-pūin ${ }^{n}$ 食吉寧仔飯 'eating Indian curries' is equivalent to saying they are "doing time".

A number of compound terms exist for things that were rare or unknown in late nineteenth-century Fujian, and therefore usually have no Amoy or Taiwanese equivalent. These relate to the history of Malaysia, the colonial government, local industries, and names of subvarieties of local fruits (Table 5.6).

TABLE 5.6 Words for local politics, officialdom, local industries, and material culture

\begin{tabular}{lll}
\hline English & Penang Hokkien & Meaning \\
\hline $\begin{array}{l}\text { area under government } \\
\text { control during the Malayan } \\
\text { emergency }\end{array}$ & $p e ́ \cdot h$-khu 白區 & white district \\
$\begin{array}{l}\text { communist-controlled } \\
\text { area during the Malayan } \\
\text { emergency }\end{array}$ & $o \cdot-k h u$ 烏區 & black district \\
$\begin{array}{l}\text { dredge for a tin mine } \\
\text { formic acid (used to } \\
\text { coagulate rubber) }\end{array}$ & $\begin{array}{l}\text { thih-chûn 鐵船 } \\
\text { chhiū-leng-chhò. }\end{array}$ & ironclad \\
& 樹㑷醋 &
\end{tabular}


TABLE 5.6 Words for local politics, officialdom, local industries, and material culture (cont.)

\begin{tabular}{|c|c|c|}
\hline English & Penang Hokkien & Meaning \\
\hline governor of Penang & ji-ông二王 & second king; viceroy \\
\hline governor's residency & jī-ông-chhù 二王厝 & second king's house \\
\hline $\begin{array}{l}\text { I.C. office (where one goes } \\
\text { to pick up one's national } \\
\text { identity card) }\end{array}$ & teng-ki-koan 登記關 & registration office \\
\hline $\begin{array}{l}\text { kebaya (the embroidered } \\
\text { blouse traditionally worn } \\
\text { by the Nyonyas) }\end{array}$ & $p o \grave{a}^{n}$-tĥn-té 半長短 & $\begin{array}{l}\text { half-long-short (a descrip- } \\
\text { tion of the garment's uneven } \\
\text { length) }\end{array}$ \\
\hline Malaysian Federal & âng-thâu-peng & the red head soldiers (the \\
\hline Reserve Unit & 紅頭兵 & $\begin{array}{l}\text { name derives from their red } \\
\text { berets) }\end{array}$ \\
\hline $\begin{array}{l}\text { mangle (used for turning } \\
\text { out sheets of rubber) }\end{array}$ & $\begin{array}{l}\text { chhiū-lêng-ká } \\
\text { 樹㑷絞 }\end{array}$ & rubber mangle \\
\hline opencast mine; tin mine & khut-lông 窟廊 & pit corridor \\
\hline $\begin{array}{l}\text { orang minyak (a type of } \\
\text { Malay ghost covered with oil) }\end{array}$ & $\begin{array}{l}o \cdot-i \hat{u} \text {-lâng 烏油儂, } \\
o \cdot-i \hat{u} \text {-kúi 烏油鬼 }\end{array}$ & $\begin{array}{l}\text { oil man (calque from Malay); } \\
\text { oil ghost }\end{array}$ \\
\hline pisang emas & kim-chio 金蕉 & $\begin{array}{l}\text { gold banana (calque from } \\
\text { Malay) }\end{array}$ \\
\hline $\begin{array}{l}\text { pisang keling (a type of } \\
\text { short, sweet banana) }\end{array}$ & $\begin{array}{l}\text { Kè-lêng-á-chio } \\
\text { 吉寧仔箬 }\end{array}$ & Indian banana \\
\hline police detective & $\begin{array}{l}\text { âm-pâi 暗牌 } \\
\text { (also known in } \\
\text { Singapore) }\end{array}$ & $\begin{array}{l}\text { hidden badge (on account of a } \\
\text { detective wearing no uniform) }\end{array}$ \\
\hline police sergeant & $\begin{array}{l}s a^{n} \text {-liáp-che }{ }^{n} \\
\text { 三粒星, } s a^{n} \text {-oáh } \\
\text { 三劃 }\end{array}$ & three stars; three stripes \\
\hline rubber plantation & $\begin{array}{l}\text { chhiū-leng-pa } \\
\text { 樹㑷芭 }\end{array}$ & $\begin{array}{l}\text { rubber forest ( } p a \text { is a probable } \\
\text { loan from Thai } p a a \text { ป่า) }\end{array}$ \\
\hline $\begin{array}{l}\text { smaller, wild variety } \\
\text { of durian }\end{array}$ & $\begin{array}{l}\text { soa }^{n} \text {-liû́-liân } \\
\text { 山榴槤 }\end{array}$ & mountain durian \\
\hline $\begin{array}{l}\text { soursop } \\
\text { (Annona muricata) }\end{array}$ & $\begin{array}{l}\text { âng-mồ-liû-liân } \\
\text { 紅毛榴槤 }\end{array}$ & $\begin{array}{l}\text { red-hair durian (presumably } \\
\text { a calque from Malay durian } \\
\text { belanda, also known } \\
\text { in Singapore) }\end{array}$ \\
\hline tin refinery & $\begin{array}{l}\text { siah-bí-lông } \\
\text { 錫米廊 }\end{array}$ & tin ore corridor \\
\hline
\end{tabular}


TABLE 5.6 Words for local politics, officialdom, local industries, and material culture (cont.)

\begin{tabular}{|c|c|c|}
\hline English & Penang Hokkien & Meaning \\
\hline to tap rubber & $\begin{array}{l}\text { koah-chhiū-leng } \\
\text { 割樹㑷, phah-chhiū- } \\
\text { leng 撲樹㑷 }\end{array}$ & to cut rubber; to hit rubber \\
\hline traffic police & $\begin{array}{l}p e ́ \cdot h \text {-kha-té } \\
\text { 白骹底 (also known } \\
\text { in Singapore) }\end{array}$ & $\begin{array}{l}\text { white leg-bottoms (a reference } \\
\text { to the white spats that are part } \\
\text { of some police uniforms) }\end{array}$ \\
\hline $\begin{array}{l}\text { type of durian with a } \\
\text { particularly green rind }\end{array}$ & $\begin{array}{l}\text { chhe.n-phôe-kián } \\
\text { 青皮囝 }\end{array}$ & green-skinned son \\
\hline $\begin{array}{l}\text { type of durian with an } \\
\text { orangey flesh }\end{array}$ & 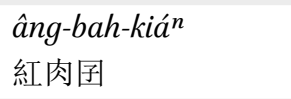 & red-fleshed son \\
\hline type of moist banana & tâ-lî-chio 銅鐳蕉 & copper coin banana \\
\hline
\end{tabular}

Penang Hokkien speakers required new words for inventions and institutions that became common throughout the industrialized and urbanized world of the late nineteenth and twentieth centuries. They were open to borrowing to fill these lexical gaps, and many terms such as 'taxi', 'radio', 'bus', 'cheque', 'gas tank', 'license', 'lorry', 'tyre', and 'commission' entered the language, modified to some extent to fit to Hokkien phonology. Sino-Japanese words for some of these new things - such as tiān-ō $a$ 電話 'telephone' - did make their way into Penang Hokkien, as did some later coinages for things that became common in the last decades of the twentieth century, such as computers and air conditioning. These were adopted into Penang Hokkien during the 1970s or 1980s. At a time when the ability to read and write Mandarin Chinese was already on the rise in Malaysian Chinese communities, there was also increased consumption of entertainment from Taiwan and Hong Kong. As the Mandarin used outside China generally followed Roc national standard of Guoyu - in preference to Putonghua promulgated as the standard within the PRC - borrowings dating from this time reflect this trend. Penang Hokkien still uses ROC léng-khi 冷氣 'air conditioning' and tiān-náu 電腦 'computer' in place of PRC coinages such as khong-tiâu 空調 and kè-sñg-ki 計算機, which are the preferred terms in Amoy. Aside from these types of loanwords, Penang Hokkien speakers have derived a wide range of neologisms that are incomprehensible to speakers of other varieties, or misunderstood because they have different meanings (Table 5.7). 
TABLE 5.7 Words for new inventions

\begin{tabular}{|c|c|c|c|}
\hline English & Penang Hokkien & $\begin{array}{l}\text { Meaning of } \\
\text { Penang term in } \\
\text { other varieties }\end{array}$ & $\begin{array}{l}\text { Amoy/Taiwan } \\
\text { equivalents }\end{array}$ \\
\hline ambulance & $\begin{array}{l}\text { âng-síp-ji-chhia } \\
\text { 紅十字車, âng-cháp- } \\
\text { jī-chhia 紅十字車,a } \\
\text { ló-kun-chhia 老君車 }\end{array}$ & $\begin{array}{l}\text { red cross vehicle, } \\
\text { doctor vehicle }\end{array}$ & $\begin{array}{l}\text { kiù-hō-chhia } \\
\text { 救護車 }\end{array}$ \\
\hline bank account & hō--kháu 戶口 & $\begin{array}{l}\text { household } \\
\text { (Taiwan), } \\
\text { household } \\
\text { registration } \\
\text { (Amoy) }\end{array}$ & $\begin{array}{l}\text { kháu-chō 口座 } \\
\text { (Taiwan), siàu-hō } \\
\text { 數號 (Amoy) }\end{array}$ \\
\hline crash helmet & thih- $b \bar{o}$ 鐵帽 & iron hat & $\begin{array}{l}a n-c h o a ̂ n-b \bar{o} \\
\text { 安全帽 }\end{array}$ \\
\hline electrical socket & tiān-thâu 電頭 & electricity head & $\begin{array}{l}\text { chhah-chō } \\
\text { 插座 }\end{array}$ \\
\hline holiday house & $\begin{array}{l}\text { chiáh-hong-lâu } \\
\text { 食風樓b }\end{array}$ & eat wind building & $\begin{array}{l}\text { piát-sū } \\
\text { 別墅 }\end{array}$ \\
\hline hospital & $\begin{array}{l}\text { ló-kun-chhù 老君厝, } \\
\text { ló-kun-lâu 老君樓,c } \\
\text { pē.n-chhù 病厝 }\end{array}$ & $\begin{array}{l}\text { doctor house, } \\
\text { doctor building, } \\
\text { sick house }\end{array}$ & $\begin{array}{l}p \bar{e}^{n}-\bar{l}^{n} \text { 病院, } i-i^{n} \\
\text { 醫院 }\end{array}$ \\
\hline life ring & pó-ke-kho·保家箍 & insurance ring & $\begin{array}{l}\text { kiù-seng-khoân } \\
\text { 救生圈 }\end{array}$ \\
\hline lifejacket & pó-ke-san 保家衫 & insurance jacket & kiù-seng-i 救生衣 \\
\hline $\begin{array}{l}\text { maternity hospital; } \\
\text { maternity ward }\end{array}$ & $s e^{n}-k i a^{n}-t \hat{n} g$ 生囝堂 & $\begin{array}{l}\text { hall for giving } \\
\text { birth }\end{array}$ & $\begin{array}{l}h \bar{u} \text {-sán-kho } i-\bar{l}^{n} \text { 婦 } \\
\text { 產科醫院 }\end{array}$ \\
\hline
\end{tabular}

a Red crosses have not been used on ambulances since the Malaysian red cross became Malaysian Red Crescent in September 1975, but the word is still widely known and used.

b chiáh-hong 食風 'to eat the wind' is a calque from Malay makan angin, with the extended meaning of taking the air or taking a holiday.

c Both pe $\bar{e}^{n}$-chhù 病厝 and ló-kun-chhù 老君厝 appear in Lo Man Yuk as Penang usage, but $p \bar{e} \cdot n_{-}$chhù 病厝, possibly a calque from older Malay rumah sakit, appears to have largely fallen out of use. 
TABLE 5.7 Words for new inventions (cont.)

\begin{tabular}{|c|c|c|c|}
\hline English & Penang Hokkien & $\begin{array}{l}\text { Meaning of } \\
\text { Penang term in } \\
\text { other varieties }\end{array}$ & $\begin{array}{l}\text { Amoy/Taiwan } \\
\text { equivalents }\end{array}$ \\
\hline $\begin{array}{l}\text { mental hospital; } \\
\text { lunatic asylum }\end{array}$ & $\begin{array}{l}\text { siáu-lâng-keng } \\
\text { 痟儂間 }\end{array}$ & $\begin{array}{l}\text { crazy person } \\
\text { house }\end{array}$ & $\begin{array}{l}\text { sin-keng-p } \bar{e}^{n-l^{n}} \\
\text { 神經病院 }\end{array}$ \\
\hline mobile phone & $\begin{array}{l}\text { chhiú-tiān 手電, } \\
\text { chhiú--êt tiān-ōa } \\
\text { 手个電話 }\end{array}$ & $\begin{array}{l}\text { torch, hand } \\
\text { telephone } \\
\text { (calque from } \\
\text { Malaysian English } \\
\text { handphone) }\end{array}$ & $c h h i u ́-k i$ 手機 \\
\hline plastic bag & $\begin{array}{l}\text { goân-chú-lông } \\
\text { 原子囊, goân-chú-tē } \\
\text { 原子袋 }\end{array}$ & $\begin{array}{l}\text { particle bag } \\
\text { (plastic-lông is } \\
\text { also commonly } \\
\text { used) }\end{array}$ & $\begin{array}{l}s o k-k a-t \bar{e} \text { 塑膠袋 } \\
\text { (Taiwan), } \\
\text { sok-liāu-te 塑料袋 } \\
\text { (Amoy) }\end{array}$ \\
\hline refrigerator & $s n g$-t $\hat{\text { 霜櫥 }}$ & ice box & peng-siu ${ }^{n}$ 冰箱 \\
\hline traffic roundabout & $\begin{array}{l}\hat{\imath}^{n-k h o \cdot-k h o a ̂ n} \\
\text { 圓䈨圈 }\end{array}$ & circle-ring-circle & $\begin{array}{l}\hat{\imath}^{n} \text {-khoân 圓圈 } \\
\text { (Taiwan), khoân-tó } \\
\text { 環島 (Amoy) }\end{array}$ \\
\hline $\begin{array}{l}\text { transformer; diesel } \\
\text { generator; car } \\
\text { battery; electricity } \\
\text { meter }\end{array}$ & tiān-siau ${ }^{n}$ 電箱 & electricity box & $\begin{array}{l}\text { piàn-ap-khi 變壓 } \\
\text { 器, chhâ-iû hoat- } \\
\text { tiān-ki 柴油發電, } \\
\text { tiān-pió 電表 }\end{array}$ \\
\hline
\end{tabular}

Several terms are derived through semantic extension, whereby a pre-existing word is used in a novel way unknown elsewhere. Some of these new usages derive from perceived resemblances, and others to well-known advertising symbols associated (or formerly associated) with the extended term. These words often retain their original meanings in addition to the extended idiomatic usage (Table 5.8).

Aside from these everyday expressions, Penang Hokkien contains a large number of slang and argot terms derived through idiomatic extension related to sexual activity, death, or other taboo subjects, such criminal as triad-related activities. These words deserve their own separate study. 


\begin{tabular}{|c|c|c|}
\hline $\begin{array}{l}\text { Penang Hokkien } \\
\text { word }\end{array}$ & $\begin{array}{l}\text { Original } \\
\text { meaning }\end{array}$ & Extended meaning \\
\hline âng-hê. 紅蝦 & red prawn & a cultivar of durian with an orangey flesh \\
\hline $\begin{array}{l}\text { bong-kha-chhuin } \\
\text { 摸尻川 }\end{array}$ & to touch a bum & $\begin{array}{l}\text { a glove puppet (so named because the hand } \\
\text { goes up the rear of the puppet) }\end{array}$ \\
\hline chhiāun $u^{n}$ gê. 象牙 & $\begin{array}{l}\text { elephant tusk; } \\
\text { ivory }\end{array}$ & a type of large, greenish banana \\
\hline chiàu-kiàn ${ }^{\text {照鏡 }}$ & $\begin{array}{l}\text { to reflect in the } \\
\text { mirror }\end{array}$ & to undergo an X-ray \\
\hline hê-bóe 蝦尾 & prawn tail & $\begin{array}{l}\text { an outboard motor, a propeller (named on } \\
\text { account of its appearance; in Taiwan thui-chin- } \\
\text { khi 推進器) }\end{array}$ \\
\hline hóe-chin 火箭 & rocket & $\begin{array}{l}\text { the Democratic Action Party (DAP; from the } \\
\text { rocket used as the party's symbol) }\end{array}$ \\
\hline $\begin{array}{l}\text { lāu-hó-thâu 老 } \\
\text { 虎頭 }\end{array}$ & tiger's head & $\begin{array}{l}\text { banknote; paper currency (from a series of } \\
\text { Malaysian banknotes that had a tiger's head as } \\
\text { the watermark, removed from } 1982 \text { onwards) }\end{array}$ \\
\hline liām-keng 念經 & $\begin{array}{l}\text { to chant a } \\
\text { Buddhist sutra }\end{array}$ & $\begin{array}{l}\text { to attend Friday prayers as a Muslim; to read } \\
\text { the Quran; to be a practising or devout Muslim }\end{array}$ \\
\hline o--káu 鳥狗 & black dog & $\begin{array}{l}\text { stout, Guinness (so named because the brand } \\
\text { of stout sold in Malaysia for many years had a } \\
\text { bulldog's head on the bottle) }\end{array}$ \\
\hline pùn-chhìn 磅秤 & pair of scales & $\begin{array}{l}\text { Barisan National (so called because the party } \\
\text { uses a pair of scales as its symbol) }\end{array}$ \\
\hline soan-téng 山頂 & $\begin{array}{l}\text { on the } \\
\text { mountain }\end{array}$ & out of town; in the suburbs; suburban \\
\hline tu-lông 豬㯙 & pigpen & a child's playpen \\
\hline
\end{tabular}

The terms highlighted in this chapter reflect a common tendency of Sinophone Southeast Asia towards creating their own terms rather than simply borrowing from Mandarin. These locally invented elements, often from purely Hokkien components, demonstrate the importance of "thinking beyond rojak". They 
also provide a case study in which Chineseness is problematized, as many Penang Hokkiens can express their identity in a variety of ways. Nevertheless, over the past twenty or so years, conditions amenable to the development of distinctive neologisms have greatly altered for Penang Chinese. Although there is considerable community interest in Penang Hokkien - resulting in the publications of dictionaries, collections of songs and poetry, a revival campaign, as well as the production of a weekly podcast and a feature film in the language the ability to speak, understand, read, and write Mandarin has increased significantly since the 198 os to the point that many Penang Chinese under the age of thirty are no longer proficient in speaking Penang Hokkien. Through increased familiarity with written Chinese, Mandarin, and the speech habits of Taiwanese Hokkien speakers, many younger speakers have begun to modify their vocabulary in accordance with their knowledge of these other languages, because they perceive these speech forms to be "purer" and more "correct" than the rojak variety spoken by their parents and grandparents. These attitudes, coupled with ethnic tensions within Malaysia, have resulted in a sharp decrease in the use of Malay loanwords and a new layer of superstrate Mandarin vocabulary entering Penang Hokkien. They do so either as direct loans in which the Mandarin pronunciation remains intact (for instance Huayu 華語 for 'Mandarin'), or as graphic loans or loans by analogy in which the Mandarin compound word generates its real or imagined cognate in Hokkien according to its characters (e.g. the same characters pronounced as Hôa-gú).

Hokkien programming on Hua Hee Dai presents a language that is still recognisable as Penang Hokkien due to its pronunciation, but reflects all of the above trends of following Mandarin usage as a standard and is fairly restricted in its use of Malay and English loanwords. The consequences of these trends for distinctive Penang vocabulary is twofold: some terms may be unknown to younger speakers and end up being replaced by new formations modelled on Mandarin, such as Tiong-i 中醫 'Chinese medicine' for Tn̂g-lâng-ióh 唐儂藥, chò-ài 做愛 'to make love' in place of kiâ ${ }^{n}-p a ̂ n g$ 行房, and Hàn-ji 漢字 'Chinese characters' in place of Tng-lâng-ji 唐儂字. Other fairly well-known terms are discarded because they are considered old-fashioned, rustic, or are seen to reflect ignorance, provincialism, or old attitudes, resulting in the replacement of Tĥg-soa ${ }^{n}$ 唐山 'Tang Mountain' by Tiong-kok 中國 'China' and kè-lêng-á angkong 吉寧仔赶公 'Hindu deities' by İn-Tō-kàu 印度教 'Hinduism'. Vocabulary that is unlikely to change in this way is that related directly to Malaysian life and material culture.

Certain historical factors have led to the formation of distinctive native vocabulary in Penang Hokkien, including low Chinese literacy, a multilingual 
and multicultural environment, the lack of entertainment media, and the relative isolation of Penang Chinese from other large communities of Hokkien speakers. Because of the high proportion of Malay and English loanwords in Penang Hokkien, neologisms derived from the native Hokkien element have not received much in the way of serious analysis or study. Currently, Penang Hokkien is undergoing a shift in its vocabulary due to intense contact and competition with Mandarin in education, entertainment, and social spheres. If Penang Hokkien survives as a spoken language in the future, and Mandarin Chinese remains the primary language of education for Penang Chinese, it is likely that many of these distinctive terms will soon be discarded and lost, so there is no better time than the present to collect and analyse them for the insights they provide into the history, culture, and mindset of the speakers of this distinctive language.

\section{References}

Barclay, Thomas, Supplement to Dictionary of the vernacular or spoken language of Amoy (Shanghai: The Commercial Press, 1923).

Batu Gantong, Chrita dahulu-kala namanya Sam Kok atau tiga negri ber-prang Siok, Gwi, sama Gor di jaman Han Teow (25 vols., Singapore: Kim Sek Chye Press, 1892).

Bruce, R., Cantonese Lessons for Malayan Students (Kuala Lumpur: Charles Grenier and Son, 1954).

Chan Boon Kim, Chrita Da-hulu-kala pasal Kow Chey Thian man-gawal-kan Tong Tye Chu pergi di negri She Thian c'hu keng (8 vols., Singapore: Fang Heng Printing Press, 1911-1913).

Chen Ronghan 陳榮翰, 'Jinxiandai Zhangzhouhua de bianhua 近現代漳州話的變化, Zhangzhou shiye daxue xuebao 漳州職業大學學報, 4 (1999): 80-87.

Chen Zhengtong 陳正統, Minnanhua Zhangqiang cidian 閩南話漳腔辭典 (Beijing: Zhonghua Shuju, 2006).

Cheng, Robert, 'Borrowing and Internal development in lexical change', Journal of Chinese Linguistics 15/1 (1987): 105-31.

Chuang Ching-ting, Chang Yueh-chin and Hsieh Feng-fan, 'Complete and not-socomplete tonal neutralization in Penang Hokkien', in Proceedings of the International Conference on Phonetics of the Languages in China (2013): 54-7.

Churchman, Catherine, 'The Eclectic Nature of Penang Hokkien Vocabulary and its Implications for Character Writing', Journal of the Taiwanese Vernacular, 9/1 (2017): $86-125$. 
de Gijzel, Luc, Penang Hokkien Dictionary (English-Hokkien) (Penang: Areca Books, 2013).

Douglas, Carstairs, Chinese-English dictionary of the vernacular or spoken language of Amoy (London: Trübner and Co, 1873).

Erancken, J.J.C. and de Grijs, C.F.M., Chineesch-Hollandsch Woordenboek van het Emoi Dialekt (Batavia: Landsdrukkerij, 1882).

Gao Ran 高然, 'Yinni Sumandala beibu de minnnan fangyan’ 印尼蘇門答臘北部的閩 南方言, in Li Rulong (ed.), Dongnanya Huaren Yuyan Yanjiu 東南亞華人語言研究 (Beijing: Beijing yuyan wenhua daxue chubanshe, 2000): 165-94.

Hing, Jia Wen, 'The Polyfunctional focus particle pun in Penang Hokkien: A Contact Perspective', in Papers from the Chulalangkorn International Student Symposium on Southeast Asian Linguistics 2017, JSEALS Special Publication 2 (2017): 51-58.

Jones, Russell, Loanwords in Indonesian and Malay (Leiden: KITLV Press, 2007).

Jones, Russell, 'The Chiangchew Hokkiens, the True Pioneers in the Nanyang', Journal of the Malaysian Branch of the Royal Asiatic Society 82/2 (2009): 39-66.

Klöter, Henning, Written Taiwanese (Wiesbaden: Harrossowitz Verlag, 2005).

Kwok, Raymond, Hokkien Baba Sayings for all Occasions (Penang: Raymond Kwok, 2005).

Li Rulong 李如龍 and Xu Ruiyuan 徐睿淵, 'Xiamen fangyan cihui yibaiduonian lai de bianhua 廈門方言詞彙一百多年来的變化, Xiamen daxue xuebao (zhexue shehuikexueban), 1 (2007): 84-91.

Li Yongqiu (Lee Eng Kew) 李永球, Zi yan zi yu 字言字語 (Penang: Borderless Trans Enterprise, 2007).

Lim, Beng S., 'Penang Peranakan Hokkien: A sociological reflection of a hybrid tongue', in Sohaimi Abdul Aziz (ed.), Penang Peranakan Chinese and Chinese Muslims: A historical and cultural journey (Penang: Persatuan Karyawan Pulau Pinang, 2010).

Lim, Beng S. and Teoh, Boon S., 'Malay lexicalized items in Penang Peranakan Hokkien', in Mark Alves, Pauls Sidwell and David Gil (eds.), SEALS VIII: Papers from the 8th meeting of the Southeast Asian Linguistics Society (Canberra: Pacific Linguistics, 2007): 148-65.

Lo Man Yuk, 'Chinese Names of Streets in Penang', Journal of the Straits Branch of the Royal Asiatic Society, Singapore (1900): 196-247.

Maryknoll Language Service Centre, Maryknoll English-Taiwanese Dictionary, 2013. http://www.taiwanesedictionary.org.

Masini, Federico, 'The Formation of Modern Chinese Lexicon and its Evolution toward a National Language: The Period from 1840 to 1898 ' (Journal of Chinese Linguistics Monograph Series 6, 1993).

Medhurst, W.H., Dictionary of the Hok-këèn Dialect of the Chinese Language according to the reading and colloquial idioms (Macao: East India Company Press, 1832). 
Morgan, Evan, Chinese New terms and Expressions with English Translations, introduction and Notes (Shanghai: Kelly and Walsh Ltd., 1913).

Newbold, T.J., Political and Statistical Account of the British Settlements in the Straits of Malacca (2 vols., London: John Murray, 1839).

Ooi Kok Hin and Tan, Julia, 'Penang Hokkien on Life Support', Penang Monthly (May 2017) https://penangmonthly.com/article.aspx?pageid=7412\&name=penang _hokkien_on_life_support.

Shellabear, William Girdlestone, 'Baba Malay', Journal of the Straits Branch of the Royal Asiatic Society, 65 (1913): 49-63.

Sim, Tze wei, 'Why are the Native Languages of the Chinese Malaysians in Decline?', Journal of the Taiwanese Vernacular, 4/1 (2012): 62-95.

Soon, Samantha S.M., Tonal assignment of Malay loanwords in Penang Hokkien (MA thesis, Nanyang Technological University, 2014).

Tan Choon Hoe, Learn to Speakpenang Hokkien Dialect (Penang: Tan Choon Hoe, 2001). Tan Choon Hoe, Penang Hokkien Dialect for Penangites and Tourists (Penang: Tan Choon Hoe, 2008).

Tan Choon Hoe, Penang Hokkien Dialect Conversations (Penang: Tan Choon Hoe, 2010).

Tan Siew Imm, Penang Hokkien-English Dictionary (Kuala Lumpur: Sunway Education group, 2016).

Wu Wenxin 吳文芯, “Malaixiya “Bincheng Fujianhua” tezhengci yanjiu 馬來西亞“檳 城福建話”特徵詞研究, Quanzhou shifanxuyuan xuebao 泉州師範學院學報, 32/1 (2014): 66-70.

Xu Jitun 許極燉, Taiwanhua tonglun (Taipei: SMC Publishing, 2000).

Ye Qianqing (Yip Xhien Ching) 葉千菁, Malaixiya Bincheng Minnanyuyinyun yanjiu 馬 來西亞檳城閩南語音韻研究 (A Study on the Phonology of Southern Min in Penang, Malaysia) (MA thesis, National Taiwan University, 2014).

Zhou Changji 周長楫 (ed.), Minnanhua dacidian 閩南話大詞典 (Fuzhou: Fujian renmin chubanshe, 2006).

Zhou Changji 周長楫, Minnanhua gaishuo 閩南話概說 (Fuzhou: Fujian renmin chubanshe, 2010).

Zhou Changji 周長楫 and Zhou Qinghai 周清海, Xinjiapo Minnanhua gaishuo 新加坡 閩南話概說 (Xiamen: Xiamen daxue chubanshe, 2000). 